\title{
Problems and guide lines of logistic digitalization in trade industry
}

\author{
Liudmila A. Myasnikova \\ Department of logistics and supply \\ chain management \\ Saint Petersburg State University of \\ Economics, \\ St. Petersburg, Russia \\ mjasnikowal@mail.ru
}

\begin{abstract}
Digital transformation has affected all spheres of society and business. Trade industry being one of the leaders in digitalization is not an exception. The technologies of artificial intelligence, computer vision, virtual and augmented reality, predictive analytics have been widely developed. In the context of technological development based on digital technologies, the interaction of humans and machines is becoming a key thread of conversation. The desire to use the opportunity to more accurately follow the consumer needs at a lower cost determines the main trend of changes - the transition to mass customization. The requirements for delivery service improvement, cost cutting and personalization extension emphasize the importance of the logistics in the development of ecosystems. At the same time, digitalization is associated with business security and confidentiality of personal data, which is associated with significant expenses and risks.
\end{abstract}

The leaders in the traditional business models revision and digitalization of trade are the largest global companies. The economies of scales allow them to create new infrastructure and hardware to transform offline and online trading, taking into account their advantages in practice. Unstable and dynamic environment forces trading companies to monitor the efficiency of the tools in use.

Country differences in digital technologies development have good reason. In modern Russian conditions, it is possible to use the experience of foreign countries and companies to study current trends for the development of native strategies and future risk assessment.

Digital transformation is changing everyday life of the people whose demands are subject to dynamic changes. It means that this work should be based on a systematic approach that takes into account the interests of all the participants, internal and external environmental instability, dynamics and possible inversion of preferences.

Keywords - logistics, trade, retail, digitalization, omnichannel, client orientation, inversion

\section{INTRODUCTION}

Logistics as a "circulatory system" of any business should be transformed under the influence of new requirements for efficiency, customer focus, mobility and flexibility to choose the right growth strategy. It is necessary to solve actual logistic problems using the new opportunities offered by digital transformation.

Almost concurrently foreign scientists carried out several studies $[1,2,3]$, which allow us to offer probable scenarios and trends of the development of both society as a whole and specific fields of activity, in particular logistics.

Thus, the Deutsche Post DHL Group initiated a futurological study "Delivering Tomorrow: Logistics in 2050" [1], which identified 5 scenarios (table 1), taking into account some likely models of trade and consumption development, manufacturing technologies, social trends, climate changes and their impact on the behavioral and value priorities of consumers.

TABLE 1. TRANSFORMATION OF LOGISTICS IN THE CONTEXT OF FUTURE SCENARIOS

\begin{tabular}{|c|c|c|c|}
\hline $\begin{array}{l}\text { The name } \\
\text { of the script }\end{array}$ & $\begin{array}{c}\text { Main } \\
\text { characteristic }\end{array}$ & $\begin{array}{l}\text { Execution } \\
\quad \text { risks }\end{array}$ & $\begin{array}{l}\text { Special Aspects } \\
\text { of Logistics }\end{array}$ \\
\hline $\begin{array}{l}\text { Scenario } 1 . \\
\text { Untamed } \\
\text { economy - } \\
\text { impending } \\
\text { collapse }\end{array}$ & $\begin{array}{l}\text { Uncontrolled mass } \\
\text { consumption. } \\
\text { Ruthless use of } \\
\text { natural resources }\end{array}$ & $\begin{array}{l}\text { Growth of } \\
\text { anthropogenic } \\
\text { load on nature. } \\
\text { Accelerating } \\
\text { climate change. } \\
\text { Supply chain } \\
\text { disruption }\end{array}$ & $\begin{array}{l}\text { Increased demand } \\
\text { for transport and } \\
\text { logistic services. } \\
\text { Quick goods } \\
\text { exchange among the } \\
\text { centers of } \\
\text { consumption }\end{array}$ \\
\hline $\begin{array}{l}\text { Scenario } 2 . \\
\text { Mega- } \\
\text { efficiency in } \\
\text { megacities }\end{array}$ & $\begin{array}{l}\text { Urban expansion. } \\
\text { Megalopolises as } \\
\text { global management } \\
\text { centers. } \\
\text { Concept of } \\
\text { environment in } \\
\text { urban development. } \\
\text { Robotization of } \\
\text { manufacturing and } \\
\text { service industries. } \\
\text { Collaboration } \\
\text { (resources sharing) }\end{array}$ & $\begin{array}{l}\text { Overflow of } \\
\text { urban } \\
\text { population. } \\
\text { Environmental } \\
\text { pollution }\end{array}$ & $\begin{array}{l}\text { Implementation of } \\
\text { highly efficient } \\
\text { traffic control } \\
\text { systems. } \\
\text { Global transport } \\
\text { systems provide } \\
\text { convenient routes of } \\
\text { communication } \\
\text { among } \\
\text { megalopolises } \\
\text { around the world. } \\
\text { Efficient logistics } \\
\text { systems of urban } \\
\text { management }\end{array}$ \\
\hline $\begin{array}{c}\text { Scenario } 3 . \\
\text { Customized } \\
\text { lifestyles }\end{array}$ & $\begin{array}{l}\text { Customized } \\
\text { consumption. } \\
\text { Manufacturing is } \\
\text { carried out by } \\
\text { consumers } \\
\text { themselves. } \\
\text { Regionalization of } \\
\text { production. } \\
\text { Decentralization of } \\
\text { energy } \\
\text { consumption }\end{array}$ & $\begin{array}{c}\text { Data protecting } \\
\text { when } \\
\text { transferring } \\
\text { schemes used } \\
\text { in 3D printers }\end{array}$ & $\begin{array}{c}\text { Regionalization } \\
\text { of traffic. } \\
\text { Decentralization of } \\
\text { infrastructure } \\
\text { management. } \\
\text { Reduction of } \\
\text { distances of finished } \\
\text { and semi-finished } \\
\text { product } \\
\text { transportation. } \\
\text { Effective system of } \\
\text { "last mile" }\end{array}$ \\
\hline
\end{tabular}




\begin{tabular}{|c|c|c|c|}
\hline $\mid \begin{array}{c}\text { Scenario } 4 . \\
\text { Paralyzing } \\
\text { protectionism }\end{array}$ & $\begin{array}{l}\text { Protection of local } \\
\text { markets } \\
\text { instead of the } \\
\text { process of } \\
\text { globalization. } \\
\text { Decline in world } \\
\text { sales }\end{array}$ & $\begin{array}{l}\text { Slowdown in } \\
\text { the innovation } \\
\text { process. } \\
\text { High energy } \\
\text { prices. } \\
\text { Growing } \\
\text { international } \\
\text { tension }\end{array}$ & $\begin{array}{l}\text { Regionalization of } \\
\text { value chains. } \\
\text { Logistics providers } \\
\text { intermediate in } \\
\text { international trade }\end{array}$ \\
\hline $\begin{array}{l}\text { Scenario } 5 . \\
\text { Global } \\
\text { resilience- } \\
\text { local } \\
\text { adaptation }\end{array}$ & $\begin{array}{l}\text { High level of } \\
\text { consumption due } \\
\text { to automation and } \\
\text { reduction of prices. } \\
\text { Focusing on } \\
\text { identifying } \\
\text { weaknesses and } \\
\text { stability } \\
\text { improvement }\end{array}$ & $\begin{array}{c}\text { Climate change. } \\
\text { Frequent } \\
\text { natural } \\
\text { disasters. } \\
\text { Redundant } \\
\text { production } \\
\text { systems }\end{array}$ & $\begin{array}{l}\text { Regular supply } \\
\text { disruptions. } \\
\text { Supply chain } \\
\text { security. } \\
\text { Formation of } \\
\text { standby } \\
\text { infrastructure }\end{array}$ \\
\hline
\end{tabular}

The scenarios provided in the study can be considered as certain guidelines for development. Such linear ideas about the future will not correspond to the real conditions of connectedness, spontaneity and unpredictability of what is happening in the world. However, considering the uneven development of different countries and regions, it can be assumed that elements or certain scenarios will be actualized simultaneously. It is also necessary to take into account the political risks that have recently had less relevance in the world order: the impact of international sanctions on the economies of countries, certain industries and companies; the deterioration of state-to-state relations; local warfare; mass migration from instability zones; terror threats and impacts on infrastructure, etc.

In the coming years, we can focus on the current trend in the development of digital and communication technologies. The transition from analog to digital systems began in the 1970s. Digital transformation takes place in different industries at different speeds. The inability to solve current issues (field-testing), including the problem of limited resources, with the help of traditional approaches, pushes manufacturers towards using advanced digital technologies.

In almost all scenarios transformation of the society is carried out on the basis of the following digital technologies:

- $\quad$ physical Internet (IoT-based);

- IT standards;

- data analysis;

- cloud technologies;

- block chain;

- robotics industry and automation;

- autonomous vehicles;

- unmanned aerial vehicles / drones;

- $3 \mathrm{D}$ printing [2].

Automation of business processes involves the use of large amounts of data (Big Data) and modern information exchange technologies (Block chain). The growth of data volumes requires adequate IT infrastructure. Whereas in 2017 the amount of data stored in data centers was estimated at 370 Exabyte, according to IDC, by 2020 it will increase up to 44 Zettabyte [4]. At 2018-year end, the cost of "digitalization" increased from $18 \%$ to $28 \%$ of the IT-budgets of enterprises, and up to $34-44 \%$ with the leaders of the market. The use of block chain technology as a means of information exchange allows logistic companies to effectively manage the vehicle fleet, routing and monitoring the most important traffic parameters, which make cost saving (fuel consumption, predicative analytics of vehicle technical state, drivers abiding by norms of labor safety, etc.) available.

The number of Internet of things (IoT) devices continues to increase steadily. Analysts from IDC believe that at the end of 2025 the machines, sensors and cameras will achieve 41.6 billion devices in total number and will generate generic traffic in the amount of 79,4 ZB [5]. As Jacques Attali predicts, the objects of supervision in 20 years (by 2040) will take place of cars and household appliances as engines of growth and will take over numerous functions of the state [6].

The sociotechnical systems, built on digital platforms, digital infrastructure, big data storage, virtual reality technologies, lead to the formation of new types of relations. At the heart of contradictions between the technosphere and the infosphere there is a man as a social and biological being. At the end of 2018 PwC company in its Digital IQ study concluded that the main obstacles to the digitalization of business lie in the field related to personnel [7].

People hand over significant parts of the functions to artificial systems that operate at speeds (nanoseconds) which human beings do not live in. Increasing economic efficiency of processes and systems on a new technological basis will lead to the release of human resources that will lead in turn to the formation of a "civilization of idleness". Digitalization of the economics involves a change of instruments, but does not lead to the solution of strategic problems.

The purpose of this study is to identify modern conditions under which digital transformation of the economy and society goes on, the assessment of the stage of logistics digitalization and its development in future.

The study allows putting forward a hypothesis about the need to a nonlinear (multidimensional) approach to the use of digitalization tools in trade, assessing the effectiveness of their application in specific conditions and the probability of consumer preferences inversion.

\section{MATERIALS AND METHODS}

Scientific works of fundamental and applied nature in the field of logistics and supply chain management, digital transformation of the economy and trade, expert research on the state and prospects of the global and Russian logistics markets, periodicals and online resources, analytical reports of network retailers and experts' forecasts for the development of Russian retail and wholesale markets served as the materials for this study.

The application tasks are solved using systematic and comparative analysis, the method of scientific assessments, statistical analysis and benchmarking elements.

\section{RESUlTS}

Digital transformation has moved from the category of special requirements to the category of mandatory attributes of a highly developed business. Russian wholesale and retail market is a significant, dynamic and most susceptible to 
innovation segment of the economy. The trade share in gross domestic product and in the structure of employment is held at the level of $16-20 \%$. The turnover of wholesale trade is twice the turnover of retail trade (in $2018-81$ trillion rubles and 31.6 trillion rubles, respectively). The Russian food retail market is the 8th largest market in the world.

According to the results of 2018, the propotion of modern formats in the structure of retail trade turnover in Russia amounted to $73 \%$. According to INFOline, the degree of concentration of Russian food retail market is not yet high. While in developed markets this figure reaches 60$70 \%$, the share of the 5 largest players in the Russian market accounts for only $26 \%$ (X5 Retail Group - 10.7\%, Magnit $7.7 \%$, Lenta $-2.8 \%$, SPS-holding (Red \& White) $-2.4 \%$, Dixy $-2.1 \%$ ), and the share of $10-31.2 \%$ of the market [8, 9].

The digitalization of the Russian retail market started in the early $21^{\text {st }}$ century and went during this period through three stages:

the first is associated with the appearing of electronic document management and corporate project management systems. The effectiveness of internal processes was achieved by excluding the influence of the human factor when performing regular business procedures;

the second is the need to automatize the processes, which have become beyond man's strength (automation of sorting and order picking, warehousing, inventory accounting in warehouses and store shelves, etc.);

the third stage is associated with the appearing of online trading, which gave an impetus to the development of new models - multi-channel and omnichannel trade. As a result of such transformations, new ways of product delivery to the consumer appeared: warehouse - store - household; store household; warehouse - household; store - parcel automat, etc.

The introduction of EDI - system of electronic document management has become an important event in Russian retail. Unfortunately, digital communication between retailers and suppliers have not yet become the standard of Russian business, unlike in Western European countries.

At a certain stage, it becomes a big problem for companies to work with software implemented at different times and by different suppliers. Integration of WMS (Warehouse Management System), TMS (Transportation Management System), ERP (Enterprise Resource Planning) and MRP (Material Requirements Planning) systems requires significant funds and efforts, which in the future does not guarantee matching new tasks. The switch to the higher level of digital transformation - SaaS (Software as a service) - provides an opportunity for supply chain management and development of new services in the "single window format". This integrated solution brings together all areas of the supply chain and gives them a possibility of activating new procedures.
Digitalization affects more and more processes both within trade enterprises and in the sphere of external interactions. Key logistics processes, such as transportation, warehousing, inventory and order management are moving to digital platforms [10]. The complexity of the interaction occurs when the schemes are supplemented by the participants of online platforms, that allow the client to vary ordering parameters and other services.

The study of Russian works in the field of digitalization of trade has shown that market leaders [8, 9] follow global trends. They put into practice and test such innovative solutions as:

- $\quad$ video monitoring of items on the shelves;

- $\quad$ video monitoring of queues;

- Internet of things to control energy saving and optimize energy consumption;

- $\quad$ virtual reality for salesmen training;

- $\quad$ big data analysis is used for comprehensive business planning, assortment analysis and adjustment;

- $\quad$ computerized learning schemes allow to determine which promotional offers are interesting for customers and profitable for companies;

- $\quad$ procedures that track differences in price offers in comparison with competitors.

Retail chains are trying to apply a systematic approach to analyze and control all aspects related to consumers, operations and personnel, which leads to increased productivity, efficiency and quality of service.

The leaders of the Russian retail implement online trading projects as omnichannel program elements. Successful projects include "Perekrestok-online", working in Moscow and St. Petersburg. In 2018, the total number of orders exceeded 408 thousand [8]. However, this channel cannot yet threaten traditional trade. According to the INFOline Agency, Russian online market of basic goods reached in 2018150 billion rubles, and online food trading amounted to only 23 billion rubles. The share of online food retail in total sales accounted for only less than $0.5 \%$ of sales [11]. However, experts point out that the market is changing in the direction of diversity. Small niche online stores are becoming more attractive for buyers.

The development of parcel lockers network adds to network trade omnichannel development as well. So, in "Pyaterochka" by the end of 2018, 1599 parcel lockers were set on in 1531 stores [8].

The results of the largest international conference NRE Retail's Big Show 2019, held in New York, show dynamic approaches to trade management [12]. The change of moods of participants from "Retail Apocalypse" (2012) and "Denial of Retail" (2016) to "Return of Retail" (2017) and "Time of Changes" (2019) is indicative [13].

The guidelines of digitization are determined based on the modern consumer behaviour patterns. The environment is 
changing rapidly - new technologies, digital ecosystems and new business models are emerging. Modern customers appreciate convenience and environmental friendliness more; they require a personal approach striving to save time. They actively use digital technologies and various channels to obtain information. The consumer's path to the product becomes multi-channel. Specialists are preparing for a more active influence of customers on business models development. The time is coming when the main consumers of retail will be representatives of generation " $z$ ", who are brought up as consumers and who are the law themselves!

Russian retail heads for digital agenda, but lags far behind market-wide, in diversity and productivity. Comparison of Russian and foreign retailers shows a significant falling behind in efficiency, Russian market leaders are behind 2-5 times, particularly in terms of revenue per employee.

\section{DISCUSSION}

Digital transformation and related technologies raise serious issues for society as a whole. The true challenge of the technologies in use is that the economics and politics could exist as partners and could proactively shape digital and industrial transformation. Alternatively, future industry and trade will not be able to achieve the principle of direct access to all the necessary on-line data and technologies that help to extract the required resources from the flow at any time. This scenario is possible if the machines are networked and can communicate with each other. So far, even the most technologically advanced countries represent the connecting elements separately, and the long-term task is to create fully integrated systems [14]. "Connected" production will generate completely new forms of business and cooperation.

Benoit Montreuil proposed the idea of the Physical Internet, which implies, by analogy with the Digital Internet, the interconnection of all elements of networks through a common operating structure for transportation and processing of goods. He began his article with the words of Napoleon Bonaparte "Amateurs discuss tactics; professionals discuss logistics" [15, p. 32], which emphasize the strategic role of logistics at all times. The Physical Internet configures supply chains, business models and value delivery models, which are possible only beyond traditional ownership, and efficiency is achieved only in a fully open environment. This emphasizes that the concept of the Physical Internet is a tool to strengthen the position of globalism.

Keeping in mind the political background of modern transformations, one should point out that the post-war (19451975) "glorious thirty years" (as J. Furastier puts it) with economic stability and welfare growth on the basis of mass production, gave way to inglorious (1980-2010) thirty years - "neoliberal era". During this period, the financial and economic crisis manifested itself as an element of the compound crisis of capitalism, which grew out of control in the $70 \mathrm{~s}-80 \mathrm{~s}$ of the 20th century. During this period capitalism for its sake passed to the concept of globalization in order to totally control world markets. The global companies ranking shows that American economy primarily benefits from globalization. The limits of growth have led to an aggressive stage of competition in global markets. To maintain its position and compete with the growing associations (for example, the EU), American globalism has turned to the policy of global controlled chaos (2001 present). The problems redouble becase of "globalization of markets without globalization of law". International institutions, even when the solution of problems falls under their competence, limit themselves to effective statements or, even worse - to biased discussions and decisions.

This background testifies to the contradictions of technological and politicaleconomic development and to the fact that the former becomes the instrument of the latter.

There is a transition from "the digital" as a service to a fully digitalworld. All digital resources - from individual to corporative and industrial - are accumulated in the cloud. Risk management in this context, according to the competent opinion of Evgeny Kaspersky, ceases to work and the damage becomes unpredictable [16]. According to the risk Barometer 2019, published by Allianz insurance company, the damage by hack attacks in 2018 amounted to $\$ 600$ billion (in 2014 $\$ 445$ billion), which exceeded the damage of $\$ 208$ billion from natural disasters over the past 10 years [17]. The main danger that criminals are using more innovative methods to steal sensitive and valuable data, the cyber threat to critical infrastructure from national governments and hacker groups tied to them is growing. Such a scope and risk dynamics reduces optimism about the prospects of digital development.

The problem of supporting the strategy of unlimited linear growth of material consumption by digitalization can be considered conceptual. The cult of consumerism escalating the inner polarization of society, with unlimited consumption at one pole and poverty at the other, threatens world peace for a number of reasons. We cannot but hope that the breaking point will result from the use of collective consumption technologies as a response to economic constraints and birth of new ideologies.

In the present circumstances for stable digital development, a country needs to have its own element base, operating systems, otherwise digitalization will lead to its colonization and full controllability by external forces. One shouldn't be under the illusion that in a highly competitive environment world's most innovative economies will contribute to the emergence of new entrants equal to them. Markets are closed and competitors are not allowed to enter for quite a while. One may recall the prohibition on precision machine tools sale in 1980s, and supercomputers in 1990s. Nowadays - the prohibition against Kaspersky Lab software products and their using by the US government and the US sanctions against Huawei.

The US and EU economic sanctions have certainly had an impact on Russian economy as a whole and trade as part of it. In addition, the scope of Russian retail market participants is not so large that modern technologies adoption could ensure economical profit. Large and medium-sized businesses in 
Russian retail turnover amounts to only $49.7 \%$, the rest of the revenue falls on markets $(5,9 \%)$, small and micro bussinesses $(22,7 \%)$ and self-employed entrepreneurs outside the market $(21,7 \%)$. Low consumer demand of the population has driven discounters trade flow up $(52.7 \%)$. The share of "corner shops" is $9.9 \%$, and hypermarkets and supermarkets account for only $37.4 \%$ [9].

Despite the above problems and shortcomings, the largest retailers are introducing digital technologies and are keenly studying foreign experience. The greatest attention is paid to the automatization of warehouses, distribution and sort facility centers. In trade industry, digitalization processes should be based on automatization to improve their efficiency by means of data processing and information transfer technologies, new methods of decisionmaking.

The main global driver of robotization and automatization - the growth of labour costs - is not so obvious in Russia. For example, in X5 Retail Group, the share of personnel costs to the company's revenue was $7.7 \%$ in 2018 [8]. However, according to Boston Consulting Group, only automation and robotics have the necessary potential to reduce costs and increase productivity in distribution and maintenance processes.

It is safe to assume that retail digitalization will go on in the following directions:

- thorough automation and robotization of warehouses and distribution centers, delivery systems, order fulfillment centers and stores;

- providing end-to-end food safety throughout the supply chain;

- development of computer vision technologies to ensure the safety of retail facilities, of cash registers automated work, of robots and shop windows equipment, price tags checking and for other purposes;

- the use of analytics based on artificial intelligence to create trained chatbots, smart sensors in retail outlets, sending messages about the need to restock, to give more exact daily sales forecasts in all stores of the retail network at once, etc.;

- employment of augmented and virtual reality technologies to demonstrate the possibilities and benefits of goods at the point of sale;

- $\quad$ personification of the price offer, when using the smartphone application the buyer is offered a personalized price for goods;

- mobile services contextualization, and a lot more.

These areas of focus are relevant to diferent extents for Russian, American and Western European markets. Russian retailers are actively developing partnerships in the field of innovation, search for startups and technology exchange not only with foreign but domestic companies as well.

\section{CONCLUSIONS}

Global challenges and trends of technological development require dismission of linear visualisation of the future in favour of multiple scripts. Different scenarios of introduction of digital technologies in large cities and small remote settlements are also inevitable. The logistic operator "Russian Post" shows significant activity in this regard, implementing joint projects with X5 Retail Group placing postamats in retail stores and selling goods of the retailer in post offices, and with IKEA delivering its produce by parcels weighing up to $20 \mathrm{~kg}$ to any post office.

Retailers are actively engaged in reconfiguring their ecosystems to meet consumers' expectations. The example of Walgreen and Kroger companies partnership is bright. According to the project a consumer places an online order at Kroger, and picks up the goods in Walgreen drugstore next to the house. American retailer Target acquired Shipt company, which delivers foods [13]. Russian retailer Magnit acquires agricultural production to manage the complete supply chain and control produce quality.

The practice of foreign countries and Russia shows interest in all models of digitalization, which are being represented and developed in the modern market. The most radical scenarios for the development of society and logistics can be implemented in a global world without borders and national governments, which the world is not yet ready for. It is crucial for Russia to create its own instrumental base for business processes digitalization, which will be the key to sustainable development.

The trends of changes within the country will lead to the consolidation of companies and centralization of logistic functions under the control of key stakeholders. Keeping up with competitors in the market will be determined by the effectiveness of forms of government regulation.

In modern retail, the concept of customer focus is inseparable from technology. Technologically, digital transformation will be represented by a universal set of tools. The scope of their application will be determined by the investment potential, and such aspects as economic, organizational, social, legal, etc., will take into account the specific conditions and level of development of systems.

Continuous change of business models is inevitable. Customer preferences variability and inversion probability will call for omnichannel development not only in all digital areas, but also in traditional retail channels, providing buyers with a choice between offline, online trading and their combinations. Speaking long-term, the inversion of the trade poles is likely to happen, when the elitarian and egalitarian consumer segments will change over, and vice versa.

The variety of demands of this kind inevitably confronts logistics with complex multifaceted tasks of creating high efficiency of business processes and quality of service.

\section{REFERENCES}

[1] Logistics 2050. A Scenario Study. Series: DELIVERING TOMORROW. - Bonn : Deutsche Post AG, 2012. - 184 p.

[2] Tipping A., Kauschke P. Shifting patterns. The future of the logistics industry. PwC. 2016 [Electronic resource] // Access Mode: https://www.pwc.com/gx/en/industries/transportation- 
logistics/publications/the-future-of-the-logistics-industry.html (date accessed - 20.05.2018).

[3] Delivering the Goods: E-commerce Logistics Transformation. Report 23 October 2018 [Electronic resource] // Access Mode: https://www.weforum.org/whitepapers/delivering-the-goods-ecommerce-logistics-transformation (date accessed - 12.01.2019)

[4] 6 trends it infrastructure: the forecast for 2018 [Electronic resource] // Access Mode: https://habrahabr.ru/company/it-grad/blog/341374/ (date accessed - 20.11.2017).

[5] The average annual growth of IoT generated data exceeds $28 \%$ // Access Mode: https://iot.ru/promyshlennost/ srednegodovoy-rostgeneriruemykh-iot-dannykh-prevyshaet-28 (date accessed 20.06.2019).

[6] Attali J. A Brief History of the Future: A Brave and Controversial Look at the Twenty-First Century / Jacques Attali. - New York: Arcade Publishing, 2009. - 297 p.

[7] Study: global Digital IQ for 2018. PwC // Access Mode: https://www.pwc.ru/ru/riskassurance/assets/diq-RUS.pdf (date accessed - 20.06.2019).

[8] X5 RETAIL GROUP. Annual report 2018.311 p. [Electronic resource] // Access Mode: https://ar2018.x5.ru/en (date accessed - 16.06.2019)

[9] Annual report 2018. MAGNIT. 195 p. [Electronic resource] // Access Mode:https://ar2018.magnit.com/download/full-reports/ar_ru_annualreport_pages.pdf (date accessed - 20.06.2019).

[10] Myasnikova, L. A., Lobanova A. K. Logistics platforms for trade automation // Logistics: modern development trends: Materials of the XVIII Intern. science.-prakt. conf. 4.5 April 2019 : Part 2. / ed. col.: (resp. ed.) V.S. Lukinsky. - SPb.: The GUMRF named after admiral S.O. Makarov, 2019. - pp. 295-299.

[11] Ishchenko N. Online trade has not yet threatened the largest Russian grocery networks [Electronic resource] // Access Mode: https://www.vedomosti.ru/business/articles/2019/07/02/805543onlain-torgovlya-ugrozhaet (date accessed - 03.07.2019).

[12] Zolotukhina, E.B., Bakharev, V.V., Kapustina, I.V., Novikov, S.V., Lygina, N.I. Sales management of the chain retail establishments (2017) 15 (11), pp. 19-27.

[13] The future of retail: key digital trends in explanation of the NRF trade show retail's Big Show 2019 [Electronic resource] // Access Mode: https://habr.com/en/post/436658/ (date accessed - 20.02.2019).

[14] Gläß, R. Handel 4.0: Die Digitalisierung des Handels - Strategien, Technologien, Transformation / Rainer Gläß, Bernd Leukert. - Berlin, Heidelberg: Springer-Verlag GmbH, 2017. - 259 s.

[15] Montreuil, B. The Physical Internet and Business Model Innovation / Benoit Montreuil, Jean-François Rougès, Yan Cimon, Diane Poulin // Technology Innovation Management Review. June 2012. pp. 32-37.

[16] Yastrebova S. Evgeny Kaspersky: «Risk management in cybersecurity no longer works» [Electronic resource] // Access Mode: https://www.vedomosti.ru/technology/characters/2019/06/08/803772kasperskii (date accessed - 15.06.2019).

[17] Allianz Risk Barometer 2019. Cyber joins business interruption as a leading global risk for companies for first time [Electronic resource] // Access Mode: https://www.allianz.com/en/press/news/studies/190115 allianz-risk-barometer-2019.html (date accessed - 03.07.2019). 